\title{
The Uptake and Utilisation of Electronic Business Technology: A Case of Selected South African Small Manufacturing Industries
}

\author{
Olabanji. A. Oni \\ Molambo. J. Ramoba \\ Tafadzwa Matiza
}

Department of Business Management, University of Limpopo, Turfloop Campus, Private Bag X1106, Sovenga, 0727, South Africa

Email: olabanji.oni@ul.ac.za

Doi:10.5901/mjss.2014.v5n20p454

\section{Absract}

This paper presents the findings of a study undertaken to explore the uptake and utilisation of e-business technology amongst small manufacturers based in Polokwane, South Africa. The aim of the study was to establish the integration of e-business technology in the operations of small manufacturers as well as the utility of the adopted technologies. The study was conducted as a quantitative enquiry, with a population of $N=12$. A survey was conducted, with self administered questionnaires as the data generation instrument. Data were analysed utilising the Statistical Package for Social Sciences 21.0, with descriptive statistics as the primary approach to data analysis and presentation The survey found that although most surveyed companies had adopted e-business technologies, the majority had moderate utilisation of technology, with the financial benefits of adopting ebusiness technology being low to moderate. As a result of the survey it also emerged that small manufactures also perceive ebusiness technology can make a significant positive impact in areas of customer services, market research and distribution cost reduction. As a result the key recommendation of the study is the need for small manufacturers analyse the push and pull factors with regards to their innovation and integration of e-business technology in order for small manufacturers to be able to effectively utilise technology within their operations.

Keywords: E-business, technology, small manufactures, South Africa

\section{Introduction}

Technology in the manufacturing sector generally refers to the tools, equipment and systems used to manufacture goods. Companies use technology throughout the manufacturing process, from the design of manufactured goods to the completion of goods ready for sale and distribution (Leone, 2012). Small businesses, as well as large organisations, can take advantage of e-technology to increase flexibility, improve customer service and reduce costs (Ray \& Ray, 2006). Kollmann (2006) for instance argues that the Net Economy refers to the commercial use of electronic data networks which, via various electronic platforms, allow the conclusion of information, communication and transactional processes. To this end, web services have become an important resource to leverage, with the benefits of social networks applying to both users and companies (Enders et al., 2008; Paredes- Valverde \& Alor-Hernandez, 2012).

With particular reference to information technology, it is the aim of this study to establish the uptake and utilisation of e-business technology by small manufacturers in Polokwane, South Africa. The objectives of the study were to; a) Determine the uptake of e-technologies by small manufacturers located in Polokwane, South Africa; b) Establish the utilisation of e-business technologies by manufacturers in Polokwane, South Africa and; c) Explore the benefits that can be derived from the application of e-technologies in manufacturing companies based in Polokwane, South Africa. To achieve the fore mentioned objectives, the study addresses the following critical questions:

- What is the present and intended use of e-technologies in manufacturing companies based in Polokwane, South Africa?

- Which factors influence the adoption and utilisation of e-business technologies by manufacturers based in Polokwane, South Africa?

- What are the potential benefits for manufacturers of applying e-technologies? 


\section{Review of Literature}

The internet has become a part of everyday life and affords great opportunities for entertainment, information and marketplace exchange. A common type of e-business is online marketing. Online marketing can be used as an internet based connection where the customers, suppliers and partners become the main key of the business. Online marketing promises to open new markets and provide better service to current customers, Leone (2012). It is necessary to analyse and evaluate the e-technologies that companies apply and their effectiveness. Barua, Konana, Whinston and Yin (2004) determine that online informational capabilities lead to better financial performance, while Hartono, Santhanam and Holsapple (2007) find that superior e-business technological capability is associated with improved performance. Ebusiness technology has the capacity to reduce the amount of labour required to produce a product, assist with product design, improves its quality and allow manufacturers to respond faster and more effectively to their customer (Dunning, 2012).

There are several factors which serve to influence the adoption rate of innovation by organisations. These factors include:

- Relative advantage - the degree to which an innovation is perceived as being better than the idea it supersedes (Premkumar, 2003; Acar, Kocak, Sey \& Arditi, 2005; Wilcott, Kamal \& Qureshi, 2008; BarbaSanchev, Martinez-Ruiz \& Jimenez-Zarco, 2007; Nguyen, 2009).

- Compatibility - the degree to which an innovation is perceived as consistent with the existing values, past experiences and needs of potential adopters (Vanderslice, 2000; Grandon \& Pearson, 2003).

- Complexity- the degree to which an innovation is perceived as relatively difficult to understand and use(Vanderslice, 2000)

- Trial ability - the degree to which an innovation may be experimental with on a limited basis(Jones, 2009).

\subsection{Potential benefits of applying e-business technologies}

In the manufacturing sector computer-based manufacturing information systems help a company achieve computerintegrated manufacturing (CIM), and thus simplify, automate, and integrate many of the activities needed to quickly produce high-quality products to meet changing customer demands(Sachenko, 2007). For example, computer-aided design using collaborative manufacturing networks helps engineers collaborate on the design of new products and processes. According to Sachenko, (2007), manufacturing resource planning systems help plan the types of resources needed in the production process, while manufacturing execution systems also monitor and control the manufacturing of products on the factory floor through shop floor scheduling and control systems, controlling a physical process (process control), a machine tool (numerical control), or machines with some humanlike work capabilities (robots). E-business technology, when applied correctly, provides features such as bar codes, which can improve quality control, with digital displays and electronic controls increasing precision and speed during the manufacturing process (Dunning, 2012). This may be viewed as a motivating factor for workers in the manufacturing plant. E-business technology may also reduce the amount of labour required to produce a product, assist with product design, improves its quality and allow manufacturers to respond faster and more effectively to their customer (Dunning, 2012).

E-commerce and e-businesstechnologies on the other hand may, according to Alam, Khatibi, Ali, Ahmad, Ismail, Ismail (2007) serve to, a) Enhance customer service, b) Facilitate the management of value chain activities, c) Improve inventory control, d) Increase market reach and, e) Reduce both marketing and distribution costs. Barua, Konana, Whinston and Yin (2004) found that online informational capabilities lead to better financial performance, while Hartono et al(2007) found that superior e-business capability in a company is associated with improved performance. Therefore, one may surmise that if the right e-business technology is applied in the right way, improved business performance will result, conditional upon appropriate complementary investments in workplace practices and organisational structures and shaped by the competitive environment (Melville, Kraemer \& Gurbaxani, 2004).

\section{Methodology}

A quantitative survey was conducted for the empirical purposes of this study. The survey approach was more appropriate for this study because the aim of the study was to establish the uptake and utilisation of e-business technology by small manufacturers in Polokwane, South Africa. This study was more concerned with measuring the effects/impacts of ebusiness technological innovation in small manufacturing firms. This study is descriptive in nature and seeks to describe 
the characteristics of objects, groups, organisations or environments; tries to "paint a picture" of a given situationZikmund, Babin, Carr \& Griffin (2013). A descriptive study was undertaken because the study aimed to determine and describe what the present and intended use of e-business technologies are in small manufacturing companies, determine the influence of the use of e-technologies on productivity and also establish the perceived benefits of applying e-technologies in a small manufacturing company.

\subsection{Population and Sample}

The research study took place in Polokwane's central business destination (CBD) in the Limpopo province, South-Africa. Small manufacturing companies outside the Polokwane CBD were not part of the population and were therefore not part of the research sample. The unit of analysis for the study were the operations managers/officers of the sampled small manufacturing businesses. Convenience sampling was employed to establish the final sample frame for the study. The final population of the study was $N=17$, which represented all small manufacturing companies located in the CBD of the city of Polokwane in Limpopo.

\subsection{Data Collection and Analysis}

The survey method was implemented as the data collection approach of the study, with self-administered questionnaires utilised as the data generation instrument for the study. Questionnaires with both ordinal and Likert scale closed questions were distributed to the operations managers/officers as key informants of sampled small manufacturing companies and collected of a specified date from each company. Data generated from the survey was checked for errors before being analysed using the Statistical Package for Social Sciences (SPSS) 21.0. The results of the study are reported using descriptive statistics primarily.

\section{Results}

The study conveniently sampled all small manufacturing companies within the Polokwane CBD. From the final sample frame of $N=17$, twelve (12) completed surveys were collected from the surveyed companies resulting in a response rate of $70.59 \%$. Table 1 summarises the demographic profile of the survey participants. Of the respondents the majority, (91.67\%), were male and the minority (8.33\%) were female. The majority of respondents were between the ages of 35-44 years of age, while $37 \%$ of the respondents were between the ages of 25-34 years, meaning the remainder of the respondents (20\%) were above the age of 45 years. With regards to education $63 \%$ of the respondents hold a post-matric diploma, with the remainder having a post graduate degree. This lent credibility to the data generated from the key informants targeted for this study with regards to their knowledge of e-business technology or at the very least grasp the concept of e-business technology.

Table 1: Demographic information of franchise owners

\begin{tabular}{|c|c|c|c|c|c|c|}
\hline \multicolumn{2}{|c|}{ Gender } & \multicolumn{3}{c|}{ Age } & \multicolumn{2}{c|}{ Educational Level } \\
\hline Male & Female & $25-34$ & $35-44$ & 45 \& Above & Post-matric Diploma & Post-Graduate Degree \\
\hline $91.67 \%$ & $8.33 \%$ & $37 \%$ & $43 \%$ & $20 \%$ & $63 \%$ & $37 \%$ \\
\hline
\end{tabular}

\subsection{Utilisation of E-business Technology}

Table 2 summarises the responses of the closed questions posed to respondents with regards to the utilisation ebusiness technology within their businesses. Of particular interest to the study was the utilisation of e-business technology in: the flow of goods and raw materials within the companies; the coding system of products and materials; quality control; the manufacturing process and; marketing-related activities. 
Table 2: Summary of Closed Question Response Frequencies

\begin{tabular}{|l|c|c|c|c|c|}
\hline & \multicolumn{2}{|c|}{ Yes } & \multicolumn{2}{c|}{ No } & \\
\hline & Frequency & \%Freq N=12 & Frequency & $\%$ Freq N=12 & Total \% Freq \\
\hline $\begin{array}{l}\text { Does your company have computerised systems which help } \\
\text { with the flow of goods and raw materials? }\end{array}$ & 12 & 100.00 & 0 & 0.00 & 100 \\
\hline $\begin{array}{l}\text { Does your company have any computerised system which } \\
\text { helps in assigning bar codes? }\end{array}$ & 2 & 16.67 & 10 & 83.33 & 100 \\
\hline $\begin{array}{l}\text { Does your company have any computerised system which } \\
\text { assists in the tracking of deliveries to customers? }\end{array}$ & 4 & 33.33 & 8 & 66.67 & 100 \\
\hline $\begin{array}{l}\text { Does your company employ a quality control system to } \\
\text { monitor orders within the company? }\end{array}$ & 6 & 50.00 & 6 & 50.00 & 100 \\
\hline $\begin{array}{l}\text { Does your company have a digital display system which } \\
\text { assists employees in the manufacturing process? }\end{array}$ & 6 & 50.00 & 6 & 50.00 & 100 \\
\hline $\begin{array}{l}\text { Has e-business technology aided in the development of } \\
\text { your company image? }\end{array}$ & 10 & 83.33 & 2 & 16.67 & 100 \\
\hline
\end{tabular}

The study found all company's surveyed (100\%) had a computerised system that aided in the work flow of goods and raw materials in the companies. Significantly however, the study found that the majority of companies (83.33\%) surveyed, did not have a bar code system, with only two companies (16.67\%) reporting to have such a system in place. $66.67 \%$ of the surveyed companies also reported not having a specific system that assists the company in tracking their deliveries to their customers. The study also found that half of the companies surveyed in the study (50\%), had a quality control system in place to monitor production, while 50\% did not. Correspondingly, 50\% of the companies surveyed reported having digital systems that assisted employees in the manufacturing process. Interestingly e-business technology had aided in the development of the majority (83.33) of the surveyed companies images.

An important aspect of the effective utilisation of e-business technology is the ability of the employees of a company to effectively use the e-business technology within the company. The trial period for new systems is often the time required for training the relevant staff in using the system as well as identifying potential glitches. Table 3 summarises the findings with regards to the trail period the surveyed companies had after installing major e-business technology.

Table 3: Trial Period of new E-business Technology

\begin{tabular}{|c|c|c|c|c|c|c|c|c|c|c|}
\hline & \multicolumn{2}{|r|}{ 1-2 Months } & \multicolumn{2}{|c|}{ 3-6 Months } & \multicolumn{2}{|c|}{ 7-10 Months } & \multicolumn{2}{|c|}{$11-12$ Months } & \multicolumn{2}{|c|}{ No Trial Period } \\
\hline & Freq & $\%$ Freq $\mathrm{N}=12$ & Freq & $\%$ Freq $\mathrm{N}=12$ & Freq & $\%$ Freq $\mathrm{N}=12$ & Freq & $\%$ Freq $\mathrm{N}=12$ & Freq & $\%$ Freq $\mathrm{N}=12$ \\
\hline $\begin{array}{l}\text { How long did your company put } \\
\text { the most major computerisation } \\
\text { system on trial? }\end{array}$ & 0 & 0 & 6 & 50 & 2 & 16.67 & 0 & 0 & 4 & 33.33 \\
\hline
\end{tabular}

The results of the study indicate that at least $50 \%$ of the surveyed companies implemented a 3-6 month trial period after the installation of e-business technology, while two of the companies surveyed (16.67\%) had a 7-10 month trial period. Interestingly four of the surveyed companies (33.33\%) did not have a trail period for implementing e-business technology.

\subsection{The Impact of E-business Technology}

Table 4 summarises the statistical frequencies of the Likert Scale questions posed to respondents of the issues of the impact of e-business technology, its consistency with company values and customer needs. The Likert Scale also asked respondents to express their view on the extent to which they believed e-business technology facilitated the new product design process within their company as well as the perceived financial benefits of employing e-business technology. 
Table 4: Impact of e-business technology

\begin{tabular}{|l|c|c|c|c|c|c|}
\hline & $\% \mathbf{V H}$ & $\% \mathrm{H}$ & $\% \mathrm{M}$ & $\% \mathrm{~L}$ & $\% \mathrm{VL}$ & Cum \% \\
\hline Level of e-business technology/computerised systems usage in the company & 0.00 & 33.33 & 50.00 & 8.33 & 8.33 & 100.00 \\
\hline $\begin{array}{l}\text { Consistency between e-business technology with company values, past } \\
\text { experiences and needs of customers }\end{array}$ & 0.00 & 0.00 & 58.33 & 25.00 & 16.67 & 100.00 \\
\hline Extent of e-business technology facilitation of new product design & 8.33 & 25.00 & 33.33 & 33.33 & 0.00 & 100.00 \\
\hline Financial benefits of employing e-business technology & 8.33 & 25.00 & 16.67 & 16.67 & 33.33 & 100.00 \\
\hline
\end{tabular}

Key: VH=Very High, H=High, M= Moderate, L=Low, VL=Very Low

The results of the study indicate a moderate utilisation of e-business technology (50\%) in small manufacturing business in Polokwane, while $33 \%$ of respondents indicate a high usage of e-business technology in their business operations. Significantly, the results also point to a moderate (58.33\%) perception of e-business technology being consistent with company values, experience and customer needs, with $25 \%$ and $16.67 \%$ of respondents viewing the consistency of ebusiness technology as low and very low respectively. The respondents viewed the extent to which e-business technology facilitated new product design to be low to moderate (33.33\% respectively), while the minority of respondents (8.33\% and $25 \%$ respectively) were of the opinion that e-business technology facilitated new product design to a large extent. With regards to the financial benefits of employing e-business technology within their businesses responses were varied. However, the majority of respondents believed that employing e-business technology had very low (33.33\%) to low (16.67\%) financial benefits, with the minority of respondents (8.33\%) perceiving e-business technology as having financial benefits for their companies.

With regards to the specific impact of e-business technology on different operational activities the questionnaire asked respondents to identify the specific operational areas which e-business technology has improved, as well as the operational areas in which e-business technology could improve if implemented. Responses are summarised in Table 5:

Table 5: Current and Potential Operational areas impact of E-technology Business Technology

\begin{tabular}{|l|c|c|c|c|c|c|c|c|c|c|c|c|c|}
\hline & \multicolumn{2}{c|}{$\begin{array}{c}\text { Customer } \\
\text { Service }\end{array}$} & \multicolumn{2}{|c|}{$\begin{array}{c}\text { Management } \\
\text { Planning }\end{array}$} & \multicolumn{2}{|c|}{$\begin{array}{c}\text { Inventory } \\
\text { Control }\end{array}$} & \multicolumn{2}{c|}{$\begin{array}{c}\text { Market } \\
\text { Research }\end{array}$} & \multicolumn{2}{c|}{$\begin{array}{c}\text { Distribution } \\
\text { Costs }\end{array}$} & \multicolumn{2}{|c|}{$\begin{array}{c}\text { Overall } \\
\text { Costs }\end{array}$} \\
\hline Freq & $\begin{array}{c}\% \text { Freq } \\
\mathrm{N}=12\end{array}$ & Freq & $\begin{array}{c}\% \text { Freq } \\
\mathrm{N}=12\end{array}$ & Freq & $\begin{array}{c}\% \text { Freq } \\
\mathrm{N}=6\end{array}$ & Freq & $\begin{array}{c}\% \text { Freq } \\
\mathrm{N}=6\end{array}$ & Freq & $\begin{array}{c}\% \text { Freq } \\
\mathrm{N}=6\end{array}$ & Freq & $\begin{array}{c}\% \text { Freq } \\
\mathrm{N}=6\end{array}$ \\
\hline $\begin{array}{l}\text { In which one or more areas does e- } \\
\text { business technology improve your } \\
\text { operations? }\end{array}$ & 2 & 16.67 & 6 & 50 & 12 & 100 & 4 & 33.33 & 4 & 33.33 & 12 & 100.00 \\
\hline $\begin{array}{l}\text { In which one or more areas would e- } \\
\text { business technology improve your } \\
\text { operations if it were implemented? }\end{array}$ & 10 & 83.33 & 6 & 50 & 0 & 0 & 8 & 66.67 & 8 & 66.67 & 0 & 0.00 \\
\hline
\end{tabular}

According to the findings of this survey study e-business technology has made the most improvements in inventory control $(100 \%)$ and the overall reduction in operational costs (100\%) for the surveyed companies. $50 \%$ of respondents identified e-business technology as having improved their management planning activities, while $33.33 \%$ identified improvement in their distribution and market research activities respectively, while $16 \%$ reported an improvement in their customer service operations. Interestingly the areas not identified by respondents as areas improved by e-business technology are pointed out by respondents as areas of potential improvement. $83 \%$ of the respondents believe that ebusiness technology can improve their customer service, while $66.67 \%$ of respondents identified market research and distribution cost reduction respectively as potential areas which e-business technology can improve. $50 \%$ of respondents were of the opinion that management planning can be improved by e-business technology.

\section{Discussion}

As a result of this study it emerged that a few companies based in Polokwane's CBD use e-technologies and computerised systems at a high level with many preferring to use e-technology and computerized systems at a moderate level. This could be due to the small manufacturersnot having sufficient information and knowledge about the utility and benefits of e-business technologies to a company. The innovation theory suggests that there are differences in adopting e-business technology depending particularly on the firm's size (Teo, 2007). Manufacturers therefore, need to first look at the size of their company before choosing an innovation and e-business technology to use. Small manufacturers should analyse the push and pull factors associated with e-business technology, in order to know when and how to apply the 
appropriate e-business technologies.Nguyen (2009) and Premkumar(2003) suggest that e-business technology adoption can lower production and labour costs, add value to products \& services, and increase a firm's competitive advantage; while Acar et al (2005) also highlight that e-business technology can also enhance business processes. These benefits can also be considered as pull factors for small manufacturers to applying e- business technologies.

One may suggested that productivity improvements are realised when investment in e-business technology leads to an increase in the ratio of output value to the related input value. The use of e-business technology by small manufacturers in Polokwane, as the results suggests is limited though it helps in designing new products, it is recommended that more efforts be put into enhancing productivity by at least innovating technologies that are high in measuring material use, measuring the actual materials used and tracking the time taken in theproduction process. Adapting to technological or environmental changes and upgrades cannot be an easy task and can be mitigated by small manufacturers employing,as the results also suggest, a trial period and training employees when introducing new ebusiness technology. The importance of implementing e-business technology in small businesses cannot be overemphasised, more-so in small manufacturing businesses which often compete with larger manufacturers which utilise technology as an innovation strategy to increase their competitiveness. This study established that the small manufactures surveyed acknowledged the importance of e-business technology to specific operations within their companies. As a result this paperrecommends further qualitative research to establish the challenges and opportunities associated with the e-business technology requirements for small manufacturers.

\section{References}

Acar, E., Kocak, I., Sey, Y. \& Arditi, D. (2005). Use of information and communication technologies by SMEs in building construction. Construction Management and Economics, 23(7), pp 713-722.

Alam, S.S., Khatibi, Ali, Ahmad, M., Ismail, S. \& Ismail, H.B. (2007). Factors affecting e-commerce adoption in the electronic manufacturing companies in Malaysia. International Journal of Commerce and Management, 17(1/2), pp129-139.

Barba-Sanchez, V., Martinez-Ruiz, M.P. \& Jimenez-Zarco, A.I. (2007). Drivers, benefits and challenges of ICT adoption by SMEs: A literature review. Problems and Perspectives in Management, 5(1), pp 104-115.

Barua, A., Konana, P., Whinston, B., \& Yin, F. (2004). An empirical investigation of, net-enabled business value.MIS Quarterly, 28(4), pp 585-620.

Dunning, D. (2012). Information technology in the manufacturing industry. [Online] Available:http://www.ehow.com. (Accessed June 18, 2013)

Enders, A \&Hungenberg, H. (2008). The long tail of social networking: Revenue models of social networking sites. European Management Journal, 26(3), pp 199-211.

Grandon, E. \& Pearson, J.M. (2003). Strategic value and adoption of electronic commerce: An empirical study of Chilean small and medium businesses. Journal of Global Information Technology Management, 6(3), pp 22-43.

Hartono, E., Santhanam, R. \& Holsapple, C. (2007). Factors that contribute to Management Support System Success. Decision Support Systems, 43(1), pp 256-268

Jones, K. (2009). Requirement to social learning adoption, Journal of Information Systems and Technology Management, 9(3), pp 586-606.

Kollmann, T. (2006). What is e-entrepreneurship? - fundamentals of company founding in the net economy.International Journal of Technology Management, 33(4), pp 322-340.

Leone, S. (2012). The role and contribution of e-business in economic development. A case study. [Online] Available: http://www.elearningplace.itl.(Accessed June 18, 2013).

Melville, N, Kraemer, K.L. \& Gurbaxani, V. (2004). Information technology and organizational performance: An integrative model of IT business value. MIS Quarterly, 28(2), pp 283-322.

Nguyen, T.H. (2009). Information technology adoption in SMEs: An integrated approach. International Journal of Entrepreneurial Behaviour and Research 15(2), pp 162-186.

Paredes-Valverde, M.A, \&Alor-Hernandez. G. (2012). Developing social networks Mashups: An overview of REST-Based APIS. Procedia Technologies 3(1), pp 205-213.

Premkumar, G. (2003). A meta-analysis of research on information technology implementation in small business. Journal of Organizational Computing and Electronic Commerce, 13(2), pp 91-121.

Ray, A.W. \& Ray, J.J. (2006). Strategic benefits to SMEs from third party web services: An action research analysis. Journal of Strategic Information Systems 15(4), pp 273-291.

Sachenko, A. (2007). Introduction to e-business systems. Artur Publishers

Teo, T. (2007). Organizational characteristics, modes of internet adoption and their impact: a Singapore perspective. Journal of Global Information Management. 15(2), pp 1-17.

Vanderslice, S. (2000). Listening to Everett Rogers: diffusion of innovations and WAC. Language and Learning Across the Disciplines, 4(1), pp 22-29.

Wilcott, P., Kamal, M. \& Qureshi, S. (2008). Meeting the challenges of ICT adoption by micro-enterprises. Journal of Enterprise Information Management. 21(6), pp 616-632.

Zikmund, G, Babin, J, Carr, C. \& Graffin, M. (2013). Business research methods, 8th Ed. New York: Erin Joyner. 